International Journal of

Supply Chain

Management

(IJSCM)

Role of Sustainable Supply Chain Management on The Performance of State Corporations in Kenya

Rureri Ruth Njoki and DR. John Achuora

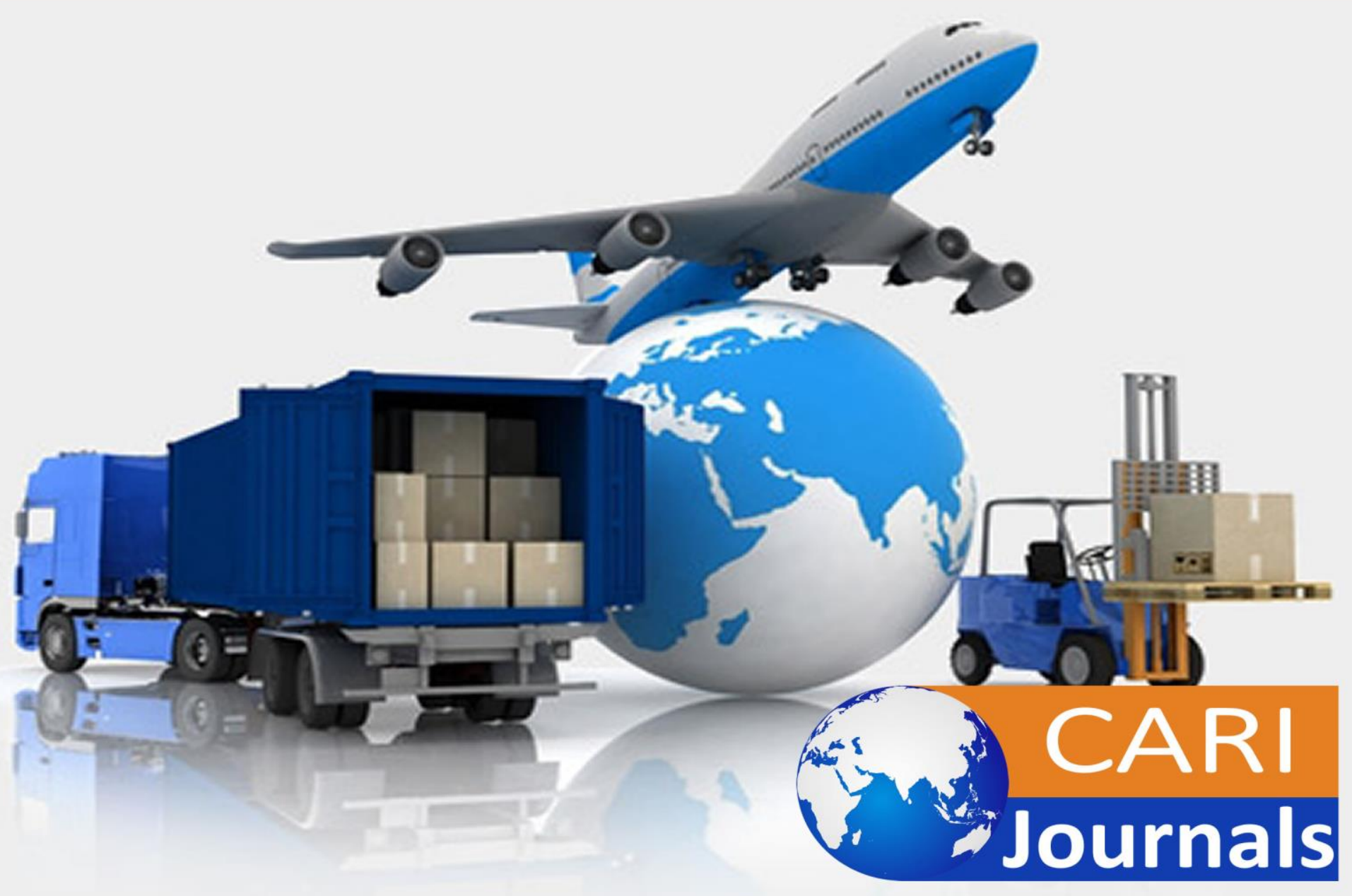




\title{
Role of Sustainable Supply Chain Management on The Performance of State Corporations in Kenya
}

\author{
${ }^{1 *}$ Rureri Ruth Njoki \\ Post Graduate Student: Department of Procurement and Logistics, \\ Jomo Kenyatta University of Agriculture and Technology \\ *Corresponding Author's E-mail: gakindu56@gmail.com \\ $2^{*}$ DR. John Achuora \\ Lecturer, Department of Procurement and Logistics \\ Jomo Kenyatta University of Agriculture and Technology
}

\begin{abstract}
Purpose: The purpose of the study was to examine the role of sustainable supply chain management on the performance of state corporations in Kenya.

Methodology: This research study adopted a descriptive research design approach. This method is preferred because it allows an in-depth study of the subject. The sample for this study shall comprise 187 state corporations in Kenya. Primary data was collected using a questionnaire whereas secondary data was collected from existing literature. The study involved three types of sampling techniques. Stratified random sampling was used and also simple random sampling after the researcher identifies homogeneity of the population. Data was analyzed through descriptive statistical methods such as means, standard deviation, frequencies and percentage. Inferential analyses were used in relation to correlation analysis and regression analysis to test the relationship between the four explanatory variables and the explained variable
\end{abstract}

Results and conclusion: The independent variables reported $\mathrm{R}$ value of .846 indicating that there is perfect relationship between dependent variable and independent variables. $R$ square value of 0.716 which means that $71.6 \%$ of the corresponding variation in performance of the state corporations can be explained or predicted by (environmental sustainability, economical sustainability, social-cultural sustainability and ethical sustainability) which indicated that the model fitted the study data. The results of regression analysis revealed that there was a significant positive relationship between dependent variable and independent variable at $(\beta=1.240), p=0.00$ $<0.05)$.

Unique contribution to theory, policy and practice: The findings of the study indicated that environmental sustainability, economical sustainability, social-cultural sustainability and ethical sustainability have a positive relationship with performance of state corporations in Kenya.

Keywords: Environmental sustainability, economical sustainability, socio-cultural sustainability and ethical sustainability 
International Journal of Supply Chain and Logistics

ISSSN 2520-3983 (Online)

Vol. 4, Issue No.1, pp 93 - 118, 2020

$\underline{\text { www.carijournals.org }}$

\subsection{INTRODUCTION}

Sustainable purchasing and supply management is a relatively recent, but rapidly emerging field (Johnsen, Miemczyk \& Howard, 2016). Despite the numerous definitions of Sustainable Supply Chain Management (SSCM), very little research describes what sustainability actually means, at a detailed level to individual business executives and determines where supply chain management (SCM) fits into those views (Paola, Daniel \& Susan, 2015).

In recent years, academics and practitioners have become increasingly interested in how organizations and their suppliers' impact on the environment, society and the economy. There is a prevailing view that there needs to be some constraint in economic and societal development, to minimize negative impacts on the environment. Growing concerns over issues such as the limitation of resources, global warming, greenhouse gases (GHGs), and consumer health have increased the urgency for firms to incorporate sustainability into their strategies (Paulraj, 2011).

Sustainability is not a fixed ideal, but an evolutionary process of improving the management of systems, through improved understanding and knowledge (Bradly, 2015).

Recently, improved understanding demands consideration of sustainability from a supply chain perspective. Sustainable procurement isn't simply about being "green" but it is also about; socially and ethically responsible purchasing, minimizing environmental impact through the supply chain, delivering economically sound solutions and good business practice (Muraguri, Waweru \& Musyimi, 2015).

The integration of economic, environmental and social facets has been at the forethought of sustainability in today's operations management due to the successful implementation of green supply chain which eventually has led to overall sustainability of firms. Sustainability calls for proponents of human, economic, as well as environmental concerns to join together to provide an everlasting life for the human species in the global ecosystem (CIPS, 2012).

According to Jonathan and Diane (2014), procurement is a key part of SSCM. Implementing sustainable policies at the procurement stage allows an organization to influence the characteristics of the products and services it will be supplied with (Preuss, 2009). There are five key principles of procurement as described by Raymond (2008) which include: value for money (VFM); ethics; competition; transparency; and accountability. Procurement also involves other issues such as culture, leadership, management, economics, environmental, ethical and political issues (Walker \& Brammer, 2012).

Sustainability is driven by an incorporation of 3E's, which include: economic; environmental and equity-driven values and policy claims. The achievement of sustainability in the built environment is by developing a 4E's (Economic, Effectiveness, Efficiency and Ethics) and 4 Poles (Economic, Social, Environmental and Technology) model of sustainability (George, Andrew \& Christopher, 2012). Some of the benefits of sustainability include, but not limited to: provision of cost savings; improved corporate image in the marketplace; creating markets for new products and services and firms are able to also secure the supply of goods and services in the light of increasingly environmental legislation, reduce wastes and improve resource efficiency (CIPS, 2012). 
International Journal of Supply Chain and Logistics

ISSSN 2520-3983 (Online)

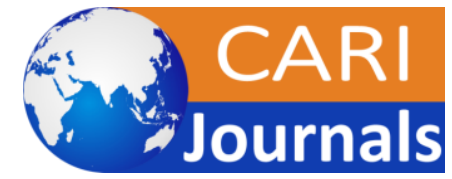

Vol. 4, Issue No.1, pp 93 - 118, 2020

www.carijournals.org

\subsection{Problem Statement}

According to a World Bank Report (2014) sustainable procurement projects consistently use social impact assessments. In Kenya state corporations accounted for $20 \%$ of the country's Gross Domestic Product (GDP), provided employment opportunities to about 300,000 people in the formal sector and 3.7 million persons in the informal sectors of the economy (KIPPRA, 2009). However, state corporations in Kenya have been experiencing a myriad of problems including non-sustainability and mismanagement of their projects (USAID, 2014).

According to a report by Delloite (2014) in Kenya, out of a sample of 52 state corporations, only 14 had adopted sustainability practices. Among many other reasons cited, this resulted to losses amounting to over 100 Million at Kenya Pipeline Corporation (KPC) in the (FY) 2013/2014. In a customer satisfaction survey of 2012 and 2013, carried out by $\mathrm{m} / \mathrm{s}$ House of Procurement Consultants, it was visibly notable that the percentage index had been decreasing that is, $52 \%$ and $43 \%$ respectively (Shale \& Rahma, 2014). KPC faces a major challenge in controlling the overall operating cost because of the constant increase of sourcing cost due to lack of sustainability strategies; this is evident by KPC posting a decrease in profit prior to tax of Sh2.42 billion compared to Sh1.5 billion noted in the previous year according to a KPC 2011 annual report.

A research carried out on the state of service delivery among state corporations in Kenya by CCG (2014) revealed that the productivity of state corporations is quite low while at the same time they continue to absorb excessive portion of the budget, becoming a principal cause of long term procurement problems (GoK, 2014). This raises questions on the level of sustainability of state corporation procurement procedures.

Several studies have been done, at the global level; Stephen and Helen (2008) point out lack of project sustainability due to low level of awareness, approaches used by developers and lack of proper feasibility study. They surveyed 100 Australian state corporation sponsored projects and reported a link between sustainability strategy and performance. They noted that sustainability strategy ensures strategic alliances are forged and aspects such as green procurement adopted. Locally, Swalehe and Odock (2015) found that Eco-design practices had a direct impact on the performance of manufacturing firms. Abdifatah (2012) concluded that sustainability planning and strategies have a direct positive impact on the performance of humanitarian organizations in delivery of relief and emergency health services.

While much research has focused on the problems facing performance of state financed projects in Kenya, not much research has been done to study sustainability strategies and their influence on performance of state corporations in Kenya. It is against this back drop that this study aims at assessing the influence of sustainable procurement practices on the performance of state corporations in Kenya. 
International Journal of Supply Chain and Logistics

ISSSN 2520-3983 (Online)

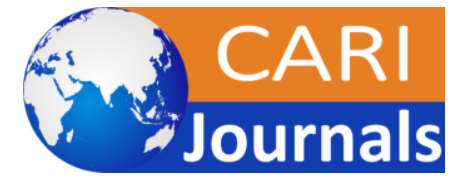

Vol. 4, Issue No.1, pp 93 - 118, 2020

www.carijournals.org

\subsection{Objectives of the Study}

i. To establish the role of environmental sustainability on performance of state corporations in Kenya.

ii. To evaluate the role of economical sustainability on performance of state corporations in Kenya.

iii. To determine the role of social-cultural sustainability on performance of state corporations in Kenya.

iv. To evaluate the role of ethical sustainability on performance of state corporations in Kenya.

\subsection{LITERATURE REVIEW}

\subsection{The Stakeholder Theory}

Stakeholders are defined as individuals, groups and organizations that have an interest in the processes and outcomes of the firm and upon whom the firm depends on for the achievement of its goals (Abend, 2008). They include employees, managers, shareholders, financiers, customers and suppliers, and may be referred to as primary or legitimate stakeholders (Phillips, 2008). Stakeholder theory is built upon the normative that businesses should serve a variety of interests rather than just those of shareholders and in so doing businesses will achieve superior performance (Bjorklund, 2011). Stakeholder theory suggests that managing stakeholders involves attending to interests and well-being of those stakeholders at a minimum (Bonn \& Fisher, 2011).

Sustainable supply chain management was founded on stakeholder theory that argues that the management aims at maximization of the stakeholders' interests and hence will put measures aimed at boosting productivity and improving on operations (Hsueh, 2015). The motivation of stakeholders in a business management setting reflects current interest in managing the issue of sustainability in inter-organizational relationships, where the firm is generally considered an unsatisfactory unit of analysis and it is necessary to take a whole system, sector based or industry view (Kumar \& Putnam, 2008). Stakeholder theory is often used to support the elaboration of other theories like RBV and Institutional theories but rarely becomes the focus of development on its own. This theory has initially been centred on defining the stakeholder concept and classifying stakeholders into categories which provide an understanding of stakeholder relationships. Stakeholder theory postulates that the purpose of business is to create value for all stakeholders and postulates that the purpose of business is to create value for all stakeholders (London \& Hart, 2010). This theory is in this study has been linked to environmental sustainability because stakeholders have to be involved in environmental issues for them to succeed. 
International Journal of Supply Chain and Logistics

ISSSN 2520-3983 (Online)

Vol. 4, Issue No.1, pp 93 - 118, 2020

$\underline{\text { www.carijournals.org }}$

\subsection{Sustainable Supply Chain Management}

\subsubsection{Supply Chain Environmental Sustainability}

There have been growing concerns over issues such as the limitation of resources, global warming, green-house gases and consumer health. This has in turn increased the urgency for firms to incorporate sustainability into their strategies (Aguilera-Caracuel \& Ortiz-de-Mandojana,, 2013). There is great reliance of technology to solve environmental problems around the world today. With the development of the internet and 24-hour news, every company is constantly under the watchful eye of the public. Unsustainable practices hidden in the supply chain has the potential to become public information extremely quickly, leaving a company's brand value damaged and shareholders displeased

\subsubsection{Supply Chain Economical Sustainability}

Economic sustainability is a critical factor in any business, which has already been studied by many researchers and in relation to operations management (Minglang, Ming, \& Wai, 2014). It can simply be interpreted as how companies stay in business, and is integrally linked to the environmental and social outcomes an organization achieves. Good financial and broader economic performance might mean that companies survive in the short-term but does not necessarily secure a long-term economic future, nor does it guarantee positive environmental and social issues which might also be a barrier to long-term survival.

\subsubsection{Supply Chain Socio-Cultural Sustainability}

Social practices and performance in operations and the supply chain encompass all management practices that affect how a firm contributes to the development of human potential or protects people from harm (Gimenez \& Tachizawa, 2012). Supply chain social responsibility differs from the more familiar notion of Corporate Social Responsibility (CSR) and refers to the chain-wide consideration and commitment to achieving social benefits, genuine and legitimate partnership and acknowledgment of different approaches to ethics (Spence \& Bourlakis, 2009).

\subsubsection{Supply Chain Ethical Sustainability}

Organizations' commitment to ethics is one of the steps towards achieving sustainable supply chain practices. Ethics address the relationships between people by providing rules of conduct that are generally agreed to govern good behavior (Kibert, 2008). The newly published ISO 20400 on sustainable procurement explains how organizations would benefit from working with suppliers who have good ethical practices. In essence, ethics governs people's behavior and controls their environmental impact. 


\subsection{Conceptual Framework}

\section{Independent Variables}

\section{Dependent Variable}

\section{SC Environmental Sustainability \\ - Green Procurement Initiatives \\ - Waste Management and Disposal \\ - Reverse Logistics Management}

\section{SC Economical Sustainability}

- Value for Money

- Strategic Alliances

- GMP and Quality Controls

\section{SC Socio-Cultural Sustainability}

- Corporate Social Responsibility

- Workplace Health and Safety

- Local Community Development

\section{SC Ethical Sustainability}

- Business Integrity

- Workplace Human Rights

- Legal and Regulatory Compliance

\section{Performance of State} Corporations

- Quality Improvement

- Cost Reduction

- Delivery Time Reduction

\section{Figure 1: Conceptual Framework}

\subsection{METHODOLOGY}

This research study adopted a descriptive research design approach. This method is preferred because it allows an in-depth study of the subject. The sample for this study shall comprise 187 state corporations in Kenya. Primary data was collected using a questionnaire whereas secondary data was collected from existing literature. The study involved three types of sampling techniques. Stratified random sampling was used and also simple random sampling after the researcher identifies homogeneity of the population. Data was analyzed through descriptive statistical methods such as means, standard deviation, frequencies and percentage. Inferential analyses were used in relation to correlation analysis and regression analysis to test the relationship between the four explanatory variables and the explained variable 
International Journal of Supply Chain and Logistics

ISSSN 2520-3983 (Online)

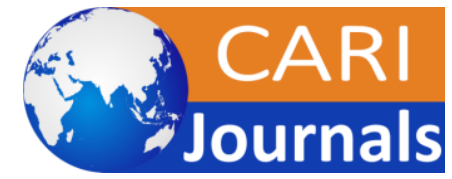

Vol. 4, Issue No.1, pp 93 - 118, 2020

www.carijournals.org

\section{0 RESULTS FINDINGS}

\subsection{Introduction}

This chapter presents results arising from the analysis of data collected using questionnaires.

\subsection{Response Rate}

A sample of 127respondents were interviewed using questionnaires that allowed the researcher to drop the questionnaire to the respondents and then collect them at a later date when they had filled the questionnaires. A total of 127 questionnares were distributed to heads of procurementas shown by table 1 . Out of the population covered, 120 were responsive, respresenting a response rate of $94 \%$. This was above the $50 \%$ which is considered adequate in descriptive statistics according to Kothari (2014).

Table 1: Response Rate of Respondents

\begin{tabular}{lll}
\hline Response & Frequency & Percentage \\
\hline Actual Response & 120 & 94 \\
Non-Response & 7 & 6 \\
Total & 127 & $100 \%$ \\
\hline
\end{tabular}

\subsection{Pilot Study}

The cronbach's alpha was computed in terms of the average inter-correlations among the items measuring the concepts. The rule of thumb for cronbach's alpha is that the closer the alpha is to 1 the higher the reliability (Kombo \& Tromp, 2015). A value of at least 0.7 is recommended. Cronbach's alpha is the most commonly used coefficient of internal consistency and stability. Consistency indicated how well the items measuring the concepts hang together as a set. Cronbach's alpha was used to measure realibilty. This was done on the four objectives of the study as shown by table 2 . The higher the coefficient, the more reliable is the test.

\section{Table 2 Reliability Results}

\begin{tabular}{lcccc}
\hline Variable & No of Items & Respondents & $\boldsymbol{\alpha}=$ Alpha & Comment \\
\hline Environmental Sustainability & 9 & 13 & 0.893 & Reliable \\
Economical Sustainability & 9 & 13 & 0.987 & Reliable \\
Social-Cultural Sustainability & 9 & 13 & 0.974 & Reliable \\
Ethical Sustainability & 9 & 13 & 0.976 & Reliable \\
\hline
\end{tabular}

\subsection{Demographic Information}

\subsubsection{Distribution of Respondents by Gender}

The study also determined the gender of the respondents. The results are submitted in figure 1 where $52 \%$ were male and $48 \%$ female. This indicates that majority of heads of procurement in the state corporations were male. This ration raises the issue of gender equity in state corporations 
in this country, but that is outside the scope of this study. A study in Hungary's government reforms among state corporations recommended more inclusion of women in state corporations because they were perceived to bring on board opinions that men did not consider important but had significant influence performance (Knight et al., 2013).

\section{Frequency}

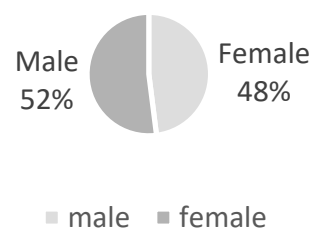

\section{Figure 2: Distributions of Respondents by Gender}

\subsubsection{Distribution of Respondents by Age}

The study determined the age distribution of the respondents. The results summarized in table 3 below. The findings indicate the respondents aged between $41-50$ were $38 \%$. 32\% of the respondents indicated that they were aged 31-40 years. Above fifty years was shown at $30 \%$. Again, this shows that those interviewed are adults capable of making independent judgments and the results of a research process involving them is deemed to be valid. The findings concur with those of Kioko (2014) who established that majority of state corporations age group is between $30 \mathrm{~s}$ and $40 \mathrm{~s}$ which is considered as the most productive age in an employee's performance.

Table 3: Distribution of Respondents by Age

\begin{tabular}{lcc}
\hline Category & Frequency & Percent \\
\hline $31-40$ years & 38 & 32 \\
$41-50$ years & 46 & 38 \\
50 and above & 36 & 30 \\
Total & $\mathbf{1 2 0}$ & $\mathbf{1 0 0}$ \\
\hline
\end{tabular}

\subsubsection{Distribution of Respondents by Level of Education}

The respondents were asked to state their highest level of education and the results were as captured in table 4 . The results indicated that majority of the respondents $48 \%$ had a degree, $27 \%$ percent had acquired a master's degree, while finally $25 \%$ were diploma holders. These findings concur with those of Gheorghe (2014) who established that majority of workers in state corporations are highly educated and that there is evidence linking education and state corporations performance. 
International Journal of Supply Chain and Logistics

ISSSN 2520-3983 (Online)

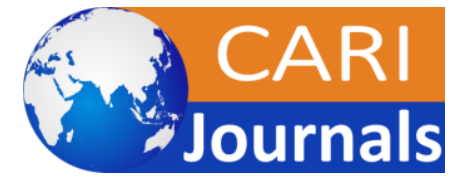

Vol. 4, Issue No.1, pp 93 - 118, 2020

www.carijournals.org

Table 4: Distribution of Respondents by Level of Education

\begin{tabular}{lll}
\hline Category & Frequency & Percent \\
\hline Diploma Level & 30 & 25 \\
Degree Level & 58 & 48 \\
Master Level & 32 & 27 \\
Total & $\mathbf{1 2 0}$ & $\mathbf{1 0 0}$ \\
\hline
\end{tabular}

\subsubsection{Distribution of Respondents by Length of Service}

The study determined the number of years the respondents had worked in the state corporations in Kenya. From the findings in table 5, 22\% had been in active service for 3-5 years. $45 \%$ had worked for 6-8 years and finally $33 \%$ and above had worked for 9 and above years. The findings of the study are in agreement with Dela (2009) who indicated that the years worked and experience of an employee helps to have better knowledge and skills which contribute to better State Corporation's performance.

Table 5: Distribution of Respondents by Length of Service

\begin{tabular}{lll}
\hline Category & Frequency & Percent \\
\hline 3-5 years & 26 & 22 \\
6-8 years & 54 & 45 \\
9 and above & 40 & 33 \\
Total & $\mathbf{1 2 0}$ & $\mathbf{1 0 0}$ \\
\hline
\end{tabular}

\subsection{Descriptive Statistics}

\subsubsection{Environmental Sustainability}

The first objective of the study was to investigate the influence of environmental sustainability on performance of state corporations in Kenya. The respondents were asked to indicate to what extent did environmental sustainability influence performance of state corporations in Kenya. Results indicated that majority of the respondents $37 \%$ agreed that it was to a very great extent, $33 \%$ said that it was to a great extent, $19 \%$ said it was moderate, while little extent and not all were at 4 and $7 \%$ respectively.

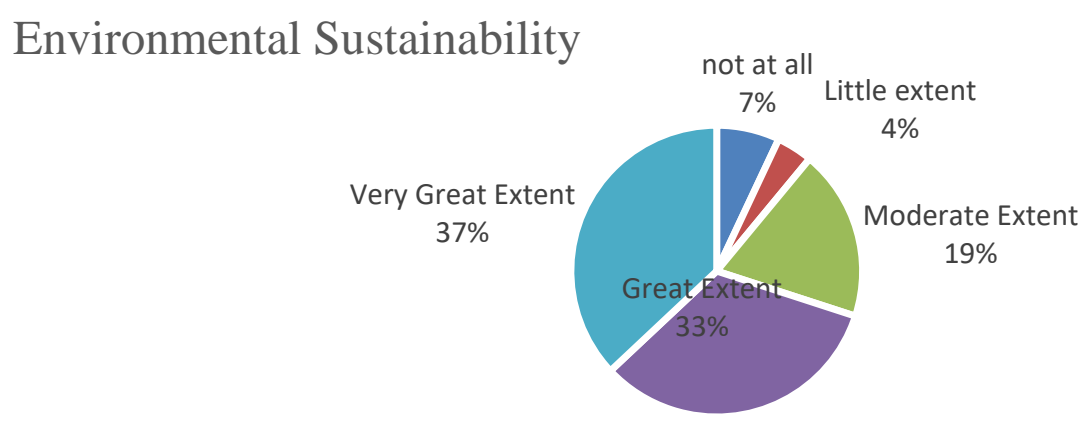


International Journal of Supply Chain and Logistics

ISSSN 2520-3983 (Online)

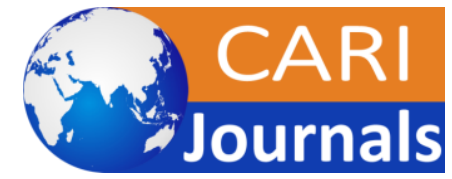

Vol. 4, Issue No.1, pp 93 - 118, 2020

www.carijournals.org

\section{Figure 3: Environmental Sustainability}

The responses were rated on a likert scale and the results presented in Table 6 below and was rated on a 5-point Likert scale ranging from; $1=$ strongly disagree to $5=$ strongly agree. The scores of ' strongly disagree' and 'disagree' have been taken to represent a statement not agreed upon, equivalent to mean score of 0 to 2.5. The score of 'neutral' has been taken to represent a statement agreed upon, equivalent to a mean score of 2.6 to 3.4. The score of 'agree' and 'strongly agree' have been taken to represent a statement highly agreed upon equivalent to a mean score of 3.5 to 5 .

Results indicated that majority of the respondents $77 \%$ agreed on statement that green procurement initiatives play a significant role in improving quality. Results indicated that majority of the respondents $60 \%$ agreed on statement that waste management and disposal play a significant role in in improving quality. Further results indicated that $63 \%$ of the respondents were in agreement that reverse logistics management plays a significant role in improving quality.

Results also indicated that $60 \%$ of the respondents agreed that green procurement initiatives play a significant role in cost reduction. Results also indicated that $54 \%$ of the respondents agreed that waste management and disposal play a significant role in cost reduction. Further results indicated that $49 \%$ of the respondents were in agreement that reverse logistics management plays a significant role in cost reduction.

Results also indicated that $61 \%$ of the respondents agreed that green procurement initiatives play a significant role in delivery time reduction. Results also indicated that $76 \%$ of the respondents agreed that waste management and disposal play a significant role in delivery time reduction. Results also indicated that $58 \%$ of the respondents agreed that reverse logistics management plays a significant role in delivery time reduction.

The average mean of the respondents was 3.68 indicating that majority of the respondents agreed with influence of environmental sustainability on performance of state corporations in Kenya. However, the responses were varied as shown by a standard deviation of 0.88 . These findings indicate that through environmental sustainability, the management of state corporations could improve their performance. This agrees with a study done by Christopher (2008) that organizations must look toward their continuous environmental sustainability improvements. The opportunities for cost savings and processes improvements can be enormous as the impact on margins is considerable. 
Table 6: Environmental Sustainability Influence on Performance of State Corporations

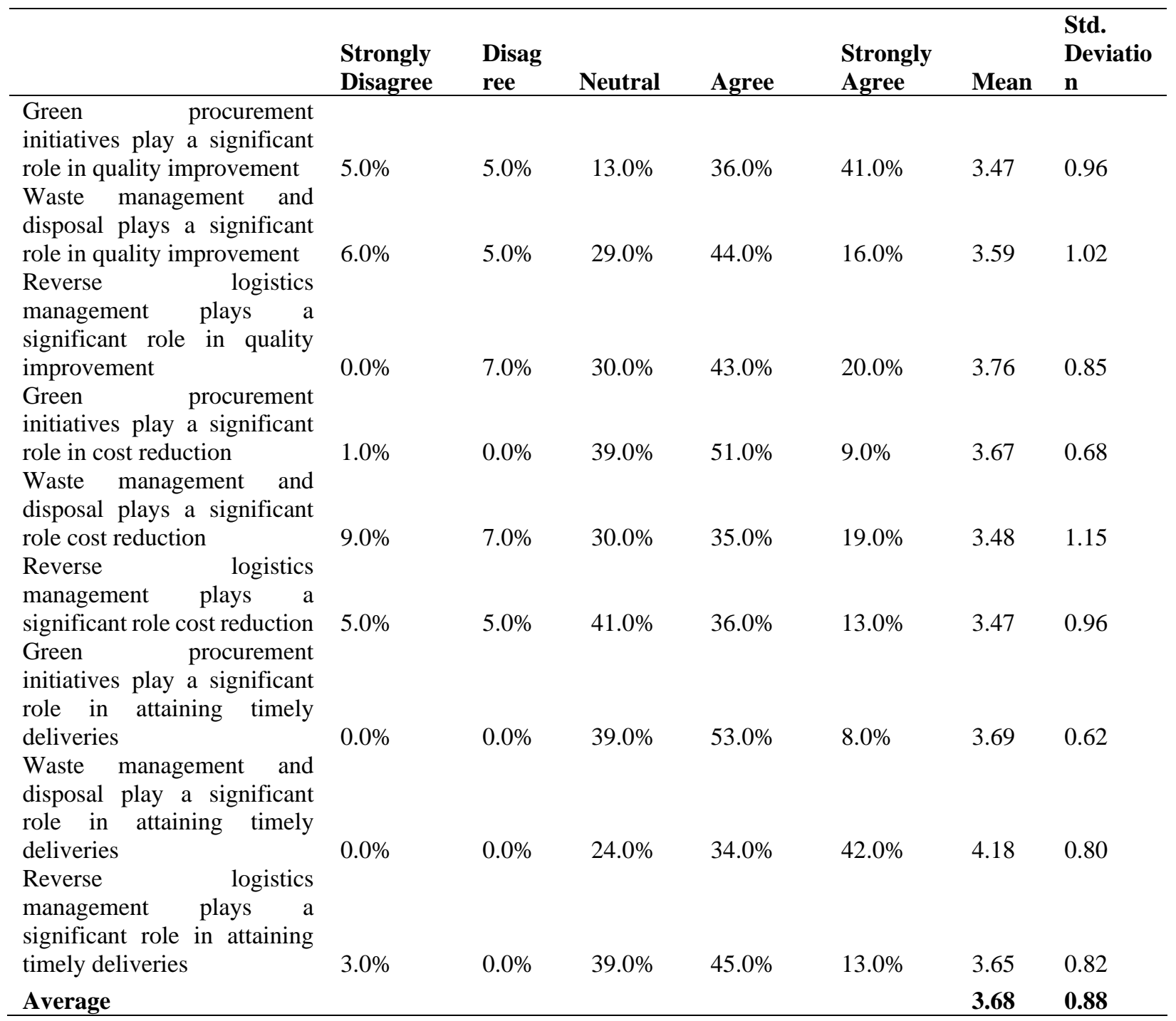

\subsubsection{Economical Sustainability}

There was also need to establish how economical sustainability influenced performance of state corporations in Kenya as the second objective. The respondents were asked to comment on extent of economical sustainability influence on performance of state corporations in Kenya. Results also showed that majority of the respondents indicated $49 \%$ was very great extent, $44 \%$ great extent, not at all was $2 \%$ while little extent and moderate extent was $3 \%$ while little extent was at $2 \%$. 


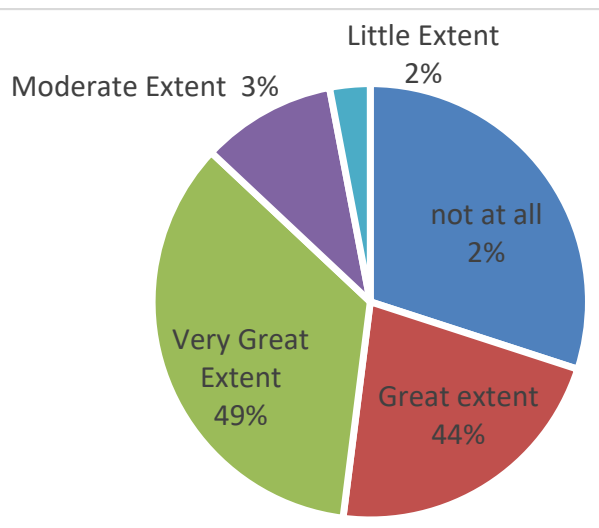

\section{Figure 4: Economical Sustainability}

Results indicated that majority of the respondents $100 \%$ agreed on the statement that value for money plays a significant role in in improving quality. Results indicated that majority of the respondents $64 \%$ agreed on the statement that strategic alliances play a significant role in in improving quality. Results indicated that majority of the respondents $47 \%$ agreed on the statement GMP and quality controls plays a significant role in in improving quality.

Results indicated that majority of the respondents $100 \%$ agreed on the statement that value for money plays a significant role in cost reduction. Results indicated that majority of the respondents 97\% agreed on the statement that strategic alliances play a significant role in cost reduction. Results indicated that majority of the respondents 93\% agreed on the statement that GMP and quality controls plays a significant role in cost reduction.

Results indicated that majority of the respondents $91 \%$ agreed on the statement that value for money plays a significant role in delivery time reduction. Results indicated that majority of the respondents $90 \%$ agreed on the statement that strategic alliances play a significant role in delivery time reduction. Results indicated that majority of the respondents $89 \%$ agreed on the statement that GMP and quality controls plays a significant role in delivery time reduction.

The average mean of the respondents was 4.16 indicating that majority of the respondents agreed with influence of economical sustainability on performance of state corporations in Kenya. However, the responses were varied as shown by a standard deviation of 0.83 . The results imply that state corporations greatly benefit when economical sustainability is embraced to reduce costs, introduce durability indices and performance ratings (Ackali, 2009). 
Table 7: Economical Sustainability Influence on Performance of State Corporations

\begin{tabular}{|c|c|c|c|c|c|c|c|}
\hline Statements & $\begin{array}{l}\text { Strongly } \\
\text { Disagree }\end{array}$ & Disagree & $\begin{array}{l}\text { Neutr } \\
\text { al }\end{array}$ & Agree & $\begin{array}{l}\text { Strongl } \\
\text { y Agree }\end{array}$ & $\begin{array}{l}\text { Mea } \\
\mathbf{n}\end{array}$ & $\begin{array}{l}\text { Std. } \\
\text { Deviatio } \\
\text { n }\end{array}$ \\
\hline $\begin{array}{l}\text { Value for money plays a significant } \\
\text { role in quality improvement }\end{array}$ & $0.0 \%$ & $0.0 \%$ & $0.0 \%$ & $48.0 \%$ & $52.0 \%$ & 4.52 & 0.50 \\
\hline $\begin{array}{l}\text { Strategic alliances play a significant } \\
\text { role in quality improvement }\end{array}$ & $0.0 \%$ & $0.0 \%$ & $36 \%$ & $40.0 \%$ & $24.0 \%$ & 3.88 & 0.77 \\
\hline $\begin{array}{l}\text { GMP and quality controls play a } \\
\text { significant role in } \\
\text { improvement }\end{array}$ & $15.0 \%$ & $19.0 \%$ & $19 \%$ & $20.0 \%$ & $27.0 \%$ & 3.25 & 1.42 \\
\hline $\begin{array}{l}\text { Value for money plays a significant } \\
\text { role in cost reduction }\end{array}$ & $0.0 \%$ & $0.0 \%$ & $0.0 \%$ & $51.0 \%$ & $49.0 \%$ & 4.49 & 0.50 \\
\hline $\begin{array}{l}\text { Strategic alliances play a significant } \\
\text { role cost reduction }\end{array}$ & $0.0 \%$ & $3.0 \%$ & $0.0 \%$ & $54.0 \%$ & $43.0 \%$ & 4.37 & 0.65 \\
\hline $\begin{array}{l}\text { GMP and quality controls play a } \\
\text { significant role cost reduction } \\
\text { Value for monev plavs a significant }\end{array}$ & $4.0 \%$ & $0.0 \%$ & $3.0 \%$ & $48.0 \%$ & $45.0 \%$ & 4.30 & 0.87 \\
\hline $\begin{array}{l}\text { Value for money plays a significant } \\
\text { role in attaining timely deliveries }\end{array}$ & $0.0 \%$ & $3.0 \%$ & $6.0 \%$ & $51.0 \%$ & $40.0 \%$ & 4.28 & 0.71 \\
\hline $\begin{array}{l}\text { Strategic alliances play a significant } \\
\text { role in attaining timely deliveries } \\
\text { GMP and quality controls plav a }\end{array}$ & $6.0 \%$ & $0.0 \%$ & $4.0 \%$ & $54.0 \%$ & $36.0 \%$ & 4.14 & 0.96 \\
\hline deliveries & $6.0 \%$ & $4.0 \%$ & $1.0 \%$ & $40.0 \%$ & $49.0 \%$ & 4.22 & 1.08 \\
\hline Average & & & & & & 4.16 & 0.83 \\
\hline
\end{tabular}

\subsubsection{Social-Cultural Sustainability}

There was also need to establish how social-cultural sustainability influenced performance of state corporations in Kenya as the third objective. The respondents were asked to comment on extent of social-cultural sustainability influence performance of state corporations in Kenya. Results indicated that majority of the respondents $48 \%$ agreed that it was to a very great extent, $45 \%$ said that it was to a great extent, $2 \%$ said it was moderate; little extent was $2 \%$ and not all at $3 \%$.

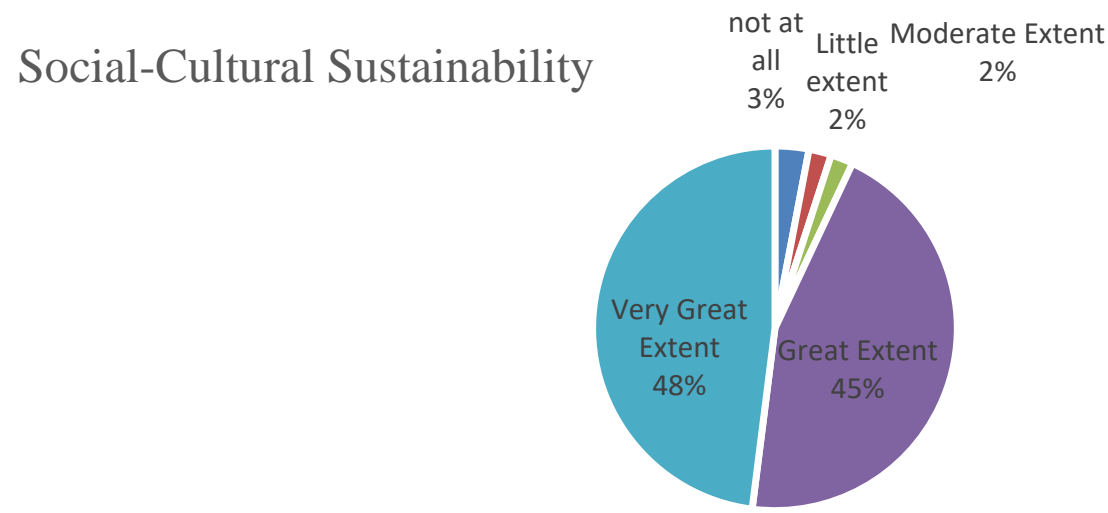

Figure 5: Social-Cultural Sustainability 
Results indicated that majority of the respondents $70 \%$ agreed on the statement that corporate social responsibility plays a significant role in in improving quality. Results also indicated that majority of the respondents $94 \%$ agreed on the statement that workplace health and safety play a significant role in in improving quality. Results also indicated that majority of the respondents $53 \%$ agreed on the statement that local community development plays a significant role in in improving quality.

Results also indicated that majority of the respondents $50 \%$ agreed on the statement that corporate social responsibility plays a significant role in cost reduction. Results also indicated that majority of the respondents $80 \%$ agreed on the statement that workplace health and safety play a significant role in cost reduction. Results also indicated that majority of the respondents $61 \%$ agreed on the statement that local community development plays a significant role in cost reduction.

Results also indicated that majority of the respondents $67 \%$ agreed on the statement that corporate social responsibility plays a significant role in delivery time reduction. Results also indicated that majority of the respondents $59 \%$ agreed on the statement that workplace health and safety play a significant role in delivery time reduction. Results also indicated that majority of the respondents $66 \%$ agreed on the statement that local community development plays a significant role in delivery time reduction.

The average mean of the respondents was 3.93 indicating that majority of the respondents agreed with influence of social-cultural sustainability on performance of state corporations in Kenya. However, the responses were varied as shown by a standard deviation of 0.93 . These findings imply that through social-cultural sustainability, state corporations can improve the value gained from social-cultural sustainability (Arthur, 2009). 
Table 8: Social-Cultural Sustainability Influence on Performance of State Corporations

\begin{tabular}{|c|c|c|c|c|c|c|c|}
\hline & $\begin{array}{l}\text { Strongly } \\
\text { Disagree }\end{array}$ & $\begin{array}{l}\text { Disagre } \\
\text { e }\end{array}$ & Neutral & Agree & $\begin{array}{l}\text { Strongl } \\
\text { y Agree }\end{array}$ & Mean & $\begin{array}{l}\text { Std. } \\
\text { Deviatio } \\
\text { n }\end{array}$ \\
\hline $\begin{array}{l}\text { Corporate social responsibility } \\
\text { plays a significant role in } \\
\text { quality improvement }\end{array}$ & $2.0 \%$ & $2.0 \%$ & $26.0 \%$ & $35.0 \%$ & $35.0 \%$ & 3.99 & 0.94 \\
\hline $\begin{array}{l}\text { Workplace health and safety } \\
\text { plays a significant role in } \\
\text { quality improvement }\end{array}$ & $0.0 \%$ & $3.0 \%$ & $3.0 \%$ & $34.0 \%$ & $60.0 \%$ & 4.51 & 0.70 \\
\hline $\begin{array}{ll}\text { Local } & \text { community } \\
\text { development } & \text { plays a }\end{array}$ & & & & & & & \\
\hline $\begin{array}{l}\text { significant role in quality } \\
\text { improvement }\end{array}$ & $5.0 \%$ & $20.0 \%$ & $22.0 \%$ & $27.0 \%$ & $26.0 \%$ & 3.49 & 1.22 \\
\hline $\begin{array}{l}\text { Corporate social responsibility } \\
\text { plays a significant role in cost } \\
\text { reduction }\end{array}$ & $0.0 \%$ & $27.0 \%$ & $23.0 \%$ & $26.0 \%$ & $24.0 \%$ & 3.47 & 1.13 \\
\hline $\begin{array}{l}\text { Workplace health and safety } \\
\text { plays a significant role cost } \\
\text { reduction } \\
\text { Local community }\end{array}$ & $0.0 \%$ & $1.0 \%$ & $19.0 \%$ & $51.0 \%$ & $29.0 \%$ & 4.08 & 0.72 \\
\hline development plays a & $1.0 \%$ & $0.0 \%$ & $38.0 \%$ & $28.0 \%$ & $33.0 \%$ & 3.92 & 0.90 \\
\hline $\begin{array}{l}\text { Corporate social responsibility } \\
\text { plays a significant role in } \\
\text { attaining timely deliveries } \\
\text { Workplace health and safety }\end{array}$ & $2.0 \%$ & $1.0 \%$ & $30.0 \%$ & $25.0 \%$ & $42.0 \%$ & 4.04 & 0.97 \\
\hline $\begin{array}{l}\text { play a significant role in } \\
\text { attaining timely deliveries }\end{array}$ & $0.0 \%$ & $0.0 \%$ & $41.0 \%$ & $30.0 \%$ & $29.0 \%$ & 3.88 & 0.83 \\
\hline $\begin{array}{l}\text { Local community } \\
\text { development plays a } \\
\text { significant role in attaining } \\
\text { timely deliveries }\end{array}$ & $1.0 \%$ & $2.0 \%$ & $31.0 \%$ & $28.0 \%$ & $38.0 \%$ & 4.00 & 0.93 \\
\hline Average & & & & & & 3.93 & 0.93 \\
\hline
\end{tabular}

\subsubsection{Ethical Sustainability}

The last objective of the study was to assess the influence of ethical sustainability on performance of state corporations in Kenya. The respondents were asked to indicate to what extent ethical sustainability influenced performance of state corporations in Kenya. Results indicated that majority of the respondents $19 \%$ agreed that it was to a very great extent, $33 \%$ said that it was to a great extent, $30 \%$ said it was moderate, while little extent was $11 \%$ and not all was at $7 \%$ respectively. 


\section{Ethical Sustainability}

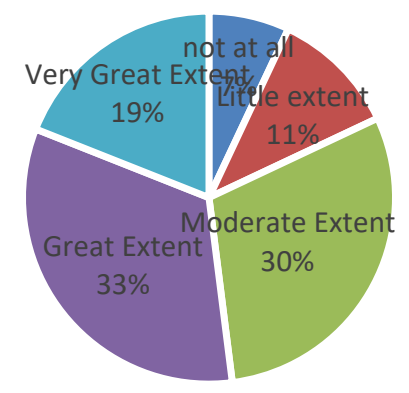

\section{Figure 6: Ethical Sustainability}

The respondents were also asked to comment on statements regarding ethical sustainability influence on performance of state corporations in Kenya. Results indicated that majority of the respondents $86 \%$ agreed on the statement that business integrity plays a significant role in in improving quality. Results also indicated that $90 \%$ of the respondents were in agreement that workplace human rights play a significant role in in improving quality. Results indicated that majority of the respondents $100 \%$ agreed on the statement that legal and regulatory compliance plays a significant role in in improving quality.

Results indicated that majority of the respondents $90 \%$ agreed on the statement that business integrity plays a significant role in cost reduction. Results indicated that majority of the respondents $96 \%$ agreed on the statement that workplace human rights play a significant role in cost reduction. Results indicated that majority of the respondents $95 \%$ agreed on the statement that legal and regulatory compliance plays a significant role in cost reduction.

Results indicated that majority of the respondents $92 \%$ agreed on the statement that business integrity plays a significant role in delivery time reduction. Results indicated that majority of the respondents $91 \%$ agreed on the statement that workplace human rights play a significant role in delivery time reduction. Results indicated that majority of the respondents $85 \%$ agreed on the statement that legal and regulatory compliance plays a significant role in delivery time reduction.

The average mean of the respondents was 4.27 indicating that majority of the respondents agreed with statements regarding ethical sustainability influence on performance of state corporations in Kenya. However, the responses were varied as shown by a standard deviation of 0.86 . These findings imply that ethical sustainability was an important aspect in the state corporations. The findings agree with David (2014) that using ethical sustainability when managing supply chains can save an organization a lot of unnecessary costs. 
International Journal of Supply Chain and Logistics

ISSSN 2520-3983 (Online)

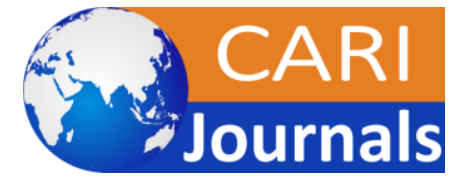

Vol. 4, Issue No.1, pp 93 - 118, 2020

www.carijournals.org

Table 9: Ethical Sustainability Influence on Performance of State Corporations

\begin{tabular}{|c|c|c|c|c|c|c|c|}
\hline & $\begin{array}{l}\text { Strongly } \\
\text { Disagree }\end{array}$ & $\begin{array}{l}\text { Disagr } \\
\text { ee }\end{array}$ & $\begin{array}{l}\text { Neutra } \\
\text { l }\end{array}$ & Agree & $\begin{array}{l}\text { Strong } \\
\text { ly } \\
\text { Agree }\end{array}$ & $\begin{array}{l}\text { Mea } \\
\text { n }\end{array}$ & $\begin{array}{l}\text { Std. } \\
\text { Deviati } \\
\text { on }\end{array}$ \\
\hline $\begin{array}{l}\text { Business integrity plays a } \\
\text { significant role in quality } \\
\text { improvement }\end{array}$ & $3.0 \%$ & $6.0 \%$ & $5.0 \%$ & $57.0 \%$ & $29.0 \%$ & 4.0 & 0.9 \\
\hline $\begin{array}{l}\text { Workplace human rights } \\
\text { play a significant role in } \\
\text { quality improvement }\end{array}$ & $4.0 \%$ & $4.0 \%$ & $2.0 \%$ & $43.0 \%$ & $47.0 \%$ & 4.3 & 1.0 \\
\hline $\begin{array}{l}\text { Legal and regulatory } \\
\text { compliance plays a } \\
\text { significant role in quality } \\
\text { improvement }\end{array}$ & $0.0 \%$ & $0.0 \%$ & $0.0 \%$ & $56.0 \%$ & $44.0 \%$ & 4.4 & 0.5 \\
\hline $\begin{array}{l}\text { Business integrity plays a } \\
\text { significant role in cost } \\
\text { reduction }\end{array}$ & $4.0 \%$ & $4.0 \%$ & $2.0 \%$ & $44.0 \%$ & $46.0 \%$ & 4.2 & 1.0 \\
\hline $\begin{array}{l}\text { Workplace human rights } \\
\text { play a significant role cost } \\
\text { reduction }\end{array}$ & $1.0 \%$ & $2.0 \%$ & $1.0 \%$ & $48.0 \%$ & $48.0 \%$ & 4.4 & 0.7 \\
\hline \begin{tabular}{llr} 
Legal and & \multicolumn{2}{c}{ regulatory } \\
compliance & plays & a \\
significant & role & cost \\
reduction & &
\end{tabular} & $2.0 \%$ & $2.0 \%$ & $1.0 \%$ & $48.0 \%$ & $47.0 \%$ & 4.4 & 0.8 \\
\hline $\begin{array}{l}\text { Business integrity plays a } \\
\text { significant role in attaining } \\
\text { timely deliveries }\end{array}$ & $2.0 \%$ & $2.0 \%$ & $1.0 \%$ & $39.0 \%$ & $56.0 \%$ & 4.5 & 0.8 \\
\hline $\begin{array}{l}\text { Workplace human rights } \\
\text { play a significant role in } \\
\text { attaining timely deliveries }\end{array}$ & $4.0 \%$ & $4.0 \%$ & $1.0 \%$ & $48.0 \%$ & $43.0 \%$ & 4.2 & 1.0 \\
\hline $\begin{array}{l}\text { Legal and regulatory } \\
\text { compliance plays a } \\
\text { significant role in attaining } \\
\text { timely deliveries }\end{array}$ & $6.0 \%$ & $6.0 \%$ & $3.0 \%$ & $45.0 \%$ & $40.0 \%$ & 4.1 & 1.1 \\
\hline Average & & & & & & 4.27 & 0.86 \\
\hline
\end{tabular}


International Journal of Supply Chain and Logistics

ISSSN 2520-3983 (Online)

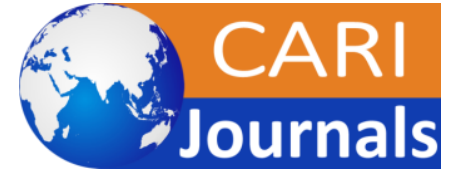

Vol. 4, Issue No.1, pp 93 - 118, 2020

WWW.carijournals.org

\subsection{Correlation Analysis}

Correlation analysis was used to determine both the significance and degree of association of the variables and also predict the level of variation in the dependent variable caused by the independent variables. The correlation technique is used to analyze the degree of association between two variables. The results of the correlation analysis are summarized in Table 10.

Table 10: Summary of Pearson's Correlations

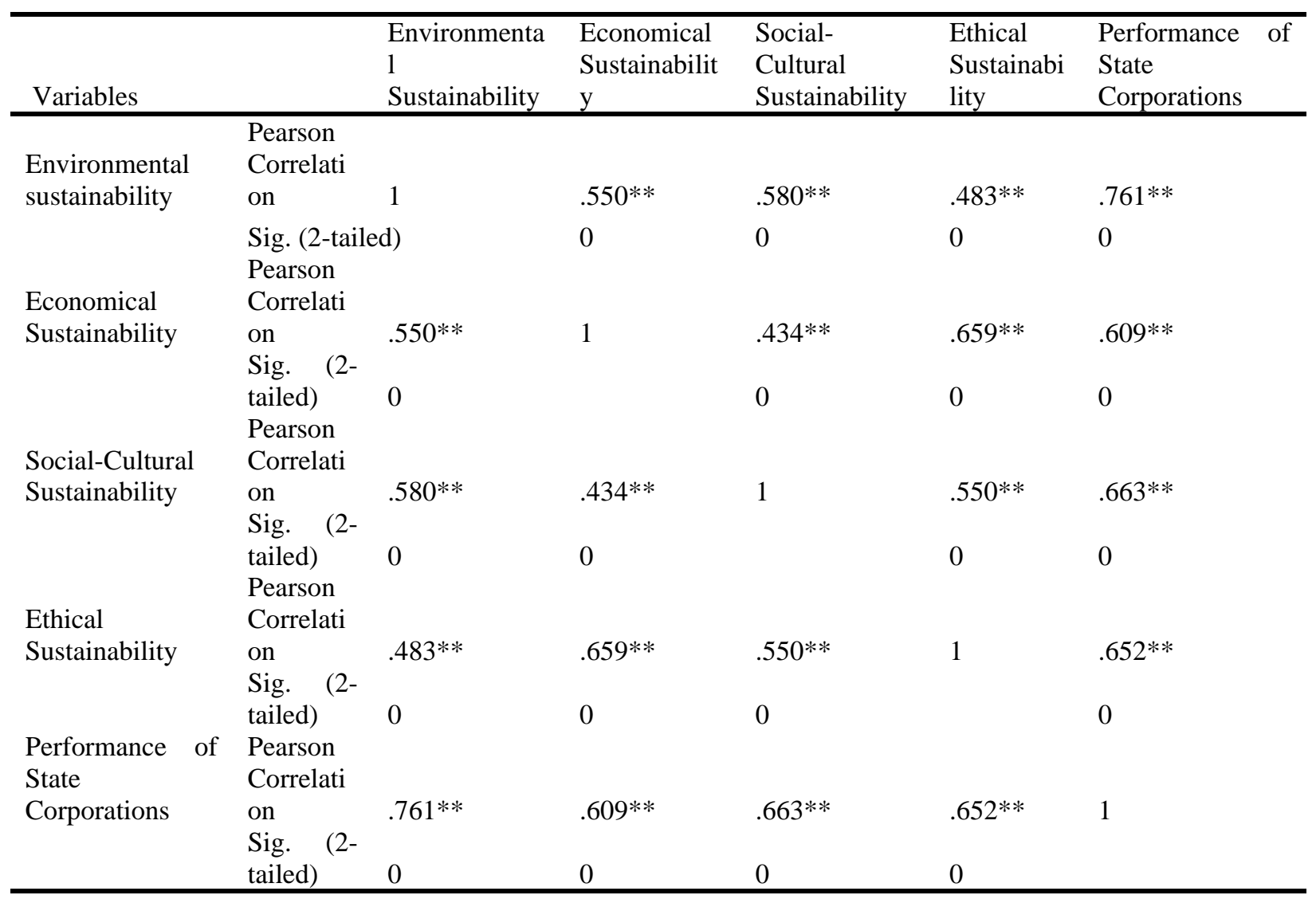

** Correlation is significant at the 0.01 level (2-tailed).

The correlation summary shown in Table 10 indicates that the associations between each of the independent variables and the dependent variable were all significant at the $95 \%$ confidence level. The correlation analysis to determine the relationship of sustainable supply chain management on performance of state corporations in Kenya, Pearson Correlation coefficient computed and tested at $5 \%$ significance level.

The results indicate that there is a positive relationship ( $\mathrm{r}=0.761)$ between environmental sustainability and performance of state corporations. In addition, the researcher found the relationship to be statistically significant at $5 \%$ level $(\mathrm{p}=0.000,<0.05)$. The correlation analysis to determine the relationship between environmental sustainability and performance of state corporations, Pearson Correlation coefficient computed and tested at 5\% significance level. 
International Journal of Supply Chain and Logistics

ISSSN 2520-3983 (Online)

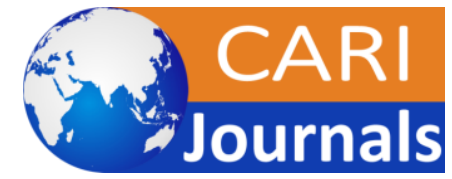

Vol. 4, Issue No.1, pp 93 - 118, 2020

www.carijournals.org

The correlation analysis to determine the relationship between economical sustainability and performance of state corporations, Pearson Correlation coefficient computed and tested at 5\% significance level. The results indicate that there is a positive relationship $(r=0.609)$ between economical sustainability and performance of state corporations. In addition, the researcher found the relationship to be statistically significant at $5 \%$ level $(\mathrm{p}=0.000,<0.05)$.

The correlation analysis to determine the relationship between social-cultural sustainability and performance of state corporations, Pearson Correlation coefficient computed and tested at 5\% significance level. The results indicate that there is a positive relationship ( $\mathrm{r}=0.663)$ social-cultural sustainability and performance of state corporations. In addition, the researcher found the relationship to be statistically significant at $5 \%$ level $(\mathrm{p}=0.000,<0.05)$.

The correlation analysis to determine the relationship between ethical sustainability and performance of state corporations, Pearson Correlation coefficient computed and tested at 5\% significance level. The results indicate that there is a positive relationship ( $\mathrm{r}=0.652)$ between ethical sustainability and performance of state corporations. In addition, the researcher found the relationship to be statistically significant at $5 \%$ level $(\mathrm{p}=0.000,<0.05)$. Hence, it is evident that all the independent variables could explain the changes in the performance of state corporations on the basis of the correlation analysis.

\subsection{Regression Analysis}

In this study multivariate regression analysis was used to determine the significance of the relationship between the dependent variable and all the independent variables pooled together. Table 11 presents the regression coefficient of independent variables against dependent variable. The results of regression analysis revealed there is a significant positive relationship between dependent variable (performance of state corporations and the independent variables (environmental sustainability, economical sustainability, social-cultural sustainability and ethical sustainability).

The independent variables reported $\mathrm{R}$ value of .846 indicating that there is perfect relationship between dependent variable and independent variables. $\mathrm{R}$ square value of 0.716 which means that $71.6 \%$ of the corresponding variation in performance of the state corporations can be explained or predicted by (environmental sustainability, economical sustainability, social-cultural sustainability and ethical sustainability) which indicated that the model fitted the study data. The results of regression analysis revealed that there was a significant positive relationship between dependent variable and independent variable at $(\beta=1.240), \mathrm{p}=0.00<0.05)$.

Table 11: Model Summary

\begin{tabular}{llllll}
\hline Model & $\mathrm{R}$ & R Square & Adjusted R Square & $\begin{array}{l}\text { Std. Error of the } \\
\text { Estimate }\end{array}$ \\
\hline 1 & $.846^{\mathrm{a}}$ & .716 & .704 & .149 \\
\hline
\end{tabular}

a. Predictors: (Constant), Environmental Sustainability, Economical Sustainability, SocialCultural Sustainability and Ethical Sustainability 
International Journal of Supply Chain and Logistics

ISSSN 2520-3983 (Online)

Vol. 4, Issue No.1, pp 93 - 118, 2020

www.carijournals.org

b. Dependent Variable: Performance of State Corporations

Table 12: ANOVA

\begin{tabular}{|c|c|c|c|c|c|c|}
\hline Model & & $\begin{array}{l}\text { Sum } \\
\text { Squares }\end{array}$ & of $\mathrm{df}$ & Mean Square & $\mathbf{F}$ & Sig. \\
\hline \multirow[t]{2}{*}{1} & Regression & 5.369 & 4 & 1.342 & 74.555 & $.000^{\mathrm{b}}$ \\
\hline & $\begin{array}{l}\text { Residual } \\
\text { Total }\end{array}$ & $\begin{array}{l}2.131 \\
7.5\end{array}$ & $\begin{array}{l}115 \\
119\end{array}$ & 0.018 & & \\
\hline
\end{tabular}

a. Predictors: (Constant), Environmental Sustainability, Economical Sustainability, SocialCultural Sustainability and Ethical Sustainability

b. Dependent Variable: Performance of State Corporations

The significance value is 0.000 which is less than 0.05 thus the model is statistically significant in predicting how environmental sustainability, economical sustainability, social-cultural sustainability and ethical sustainability influence performance of state corporations. The study therefore establishes that; environmental sustainability, economical sustainability, social-cultural sustainability and ethical sustainability influence performance of state corporations. These results agree with Paul (2011) results which indicated a positive and significant influence of sustainable supply chain management on performance of state corporations.

Table 13: Coefficients of Determination

\begin{tabular}{llccccc}
\hline $\begin{array}{l}\text { Mod } \\
\text { el }\end{array}$ & & \multicolumn{2}{c}{$\begin{array}{c}\text { Unstandardized } \\
\text { Coefficients } \\
\text { Std. Error }\end{array}$} & $\begin{array}{c}\text { Standardized } \\
\text { Coefficients } \\
\text { Beta }\end{array}$ & t & Sig. \\
\hline 1 & 1.240 & 0.260 & & 4.771 & 0.000 \\
& & 0.462 & 0.073 & 0.463 & 6.299 & 0.000 \\
& $\begin{array}{l}\text { (Constant) } \\
\text { Environmental } \\
\text { sustainability }\end{array}$ & 0.108 & 0.035 & 0.243 & 3.075 & 0.000 \\
& $\begin{array}{l}\text { Economical } \\
\text { sustainability }\end{array}$ & & & & & \\
& $\begin{array}{l}\text { Social-cultural } \\
\text { sustainability }\end{array}$ & 0.071 & 0.023 & 0.218 & 3.008 & 0.000 \\
& Ethical sustainability & 0.064 & 0.047 & 0.099 & 1.361 & 0.021 \\
\hline
\end{tabular}

a) Predictors: (Constant), Environmental Sustainability, Economical Sustainability, SocialCultural Sustainability and Ethical Sustainability

b) Dependent Variable: Performance of State Corporations

The research used a multiple regression model

$$
Y=\beta_{0}+\beta_{1} X_{1}+\beta_{2} X_{2}+\beta_{3} X_{3}+\beta_{4} X_{4}+\varepsilon
$$


International Journal of Supply Chain and Logistics

ISSSN 2520-3983 (Online)

Vol. 4, Issue No.1, pp 93 - 118, 2020

$\underline{\text { www.carijournals.org }}$

Where $\mathbf{Y}=$ Performance of State Corporations

$\boldsymbol{\beta}_{\mathbf{0}}=$ Constant

$\mathbf{X}_{\mathbf{1}}=$ Environmental Sustainability

$\mathbf{X}_{\mathbf{2}}=$ Economical Sustainability

$\mathbf{X}_{\mathbf{3}}=$ Social-Cultural Sustainability

$\mathbf{X}_{\mathbf{4}}=$ Ethical Sustainability

$\boldsymbol{\varepsilon}=$ Error Term at $95 \%$ confidence level.

The regression equation will be;

$Y=1.240+0.462 X_{1}+0.108 X_{2}+0.071 X_{3}+0.064 X_{4}$

The regression equation above has established that taking all factors into account (environmental sustainability, economical sustainability, social-cultural sustainability and ethical sustainability) constant at zero, performance of state corporations will be an index of 1.240. The findings presented also shows that taking all other independent variables at zero, a unit increase in environmental sustainability will lead to a 0.462 increase in performance of state corporations. The $\mathrm{P}$-value was 0.000 which is less than 0.05 and thus the relationship was significant.

The study also found that a unit increase in economical sustainability will lead to a 0.108 increase in in performance of state corporations. The P-value was 0.000 and thus the relationship was significant. In addition, the study found that a unit increase in social-cultural sustainability will lead to a 0.071 increase in the performance of state corporations. The P-value was 0.000 and thus the relationship was significant.

Lastly, the study found that a unit increase in ethical sustainability will lead to a 0.064 increase in the performance of state corporations. The P-value was 0.021 and hence the relationship was significant since the $\mathrm{p}$-value was lower than 0.05. The findings of the study show that, environmental sustainability contributed most to performance of state corporations.

\subsection{SUMMARY, CONCLUSION AND RECOMMENDATIONS}

\subsection{Summary of the Findings}

The regression equation above has established that taking all factors into account (environmental sustainability, economical sustainability, social-cultural sustainability and ethical sustainability) constant at zero, performance of state corporations will be an index of 1.240. The findings presented also shows that taking all other independent variables at zero, a unit increase in environmental sustainability will lead to a 0.462 increase in performance of state corporations. The P-value was 0.000 which is less than 0.05 and thus the relationship was significant.

The study also found that a unit increase in economical sustainability will lead to a 0.108 increase in in performance of state corporations. The P-value was 0.000 and thus the relationship was significant. In addition, the study found that a unit increase in social-cultural sustainability will 
International Journal of Supply Chain and Logistics

ISSSN 2520-3983 (Online)

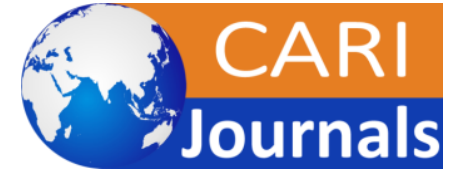

Vol. 4, Issue No.1, pp 93 - 118, 2020

www.carijournals.org

lead to a 0.071 increase in the performance of state corporations. The P-value was 0.000 and thus the relationship was significant.

Lastly, the study found that a unit increase in ethical sustainability will lead to a 0.064 increase in the performance of state corporations. The P-value was 0.021 and hence the relationship was significant since the p-value was lower than 0.05 . The findings of the study show that, environmental sustainability contributed most to performance of state corporations.

\subsection{Conclusion}

The findings of the study indicated that environmental sustainability, economical sustainability, social-cultural sustainability and ethical sustainability have a positive relationship with performance of state corporations in Kenya.

\subsection{Recommendations}

Finally, the study recommended that state corporations should embrace sustainable supply chain management so as to improve performance and further researches should to be carried out in other institutions to find out if the same results can be obtained.

\section{REFERENCES}

Abend, G. (2008). "The Meaning of Theory". Sociological Theory, Retrieved from onlinelibrary.wiley.com/ 1(7), 163-199.

Africare International (2014). HIV/AIDS related knowledge, attitudes and practice in Kenya. A conceptual perspective of Kenyan organizations, Kenya

Aguilera-Caracuel, J., \& Ortiz-de-Mandojana, N. (2013). "Green innovation and financial performance: An institutional approach". Organization and Environment, 2(6), 365-385.

Amaoko, K., Samuel, A.D. \& Samuel, F., (2016). "Sustainability and Competitive advantage from a developed economy. Journal of Global Responsibility, 7 (1), 110-125.

Amit, A. (2014). "Sustainability Strategies in Supply Chain Management". Electronic thesis and dissertations

Amol, S. \& Ashish, T. (2016). "Sustainable green supply chain management: trends and current practices", Competitiveness Review, 26 (3), 265-288

Anderson, A. R. (2008). "Cultivating the Garden of Eden: Environmental Entrepreneuring" Journal of Organizational Change Management, 11(2), 135-144

Anne, T. \& Hellen, W. (2015). "Theories in sustainable supply chain management: a structured literature review", International Journal of Physical Distribution and Logistics Management, 45 (2), 16-42

Awaysheh, A. \& Klassen, R. (2010). "The impact of supply chain structure on the use of supplier socially responsible practices", International Journal of Operations and Production Management, 30(12), 1246-1268 
International Journal of Supply Chain and Logistics

ISSSN 2520-3983 (Online)

Vol. 4, Issue No.1, pp 93 - 118, 2020

www.carijournals.org

Beske, P., \& Seuring, S. (2014). "Putting sustainability into supply chain management". Supply Chain Management: An International Journal, 1(9), 322-331.

Bjorklund, M. (2011). "Influence from the business environment on environmental purchasing drivers and hinders of purchasing green transportation services", Journal of Purchasing \& Supply Management, 17, (1), 11-22.

Bolton, P. (2009). "Government Procurement as a Policy Tool in South Africa”, Journal of Public Procurement, 4(3), 5-20.

Bonn, I. \& Fisher, J. (2011). "Sustainability: the missing ingredient in strategy", Journal of Business Ethics, 32(1), 5-14.

Bradly, A. (2015). "The business-case for community investment: Evidence from Fiji's tourism

Brettel, M., \& Voss, U. (2013). "Antecedents of management control combinations-An explanation from resource dependence theory". Schmalenbach Business Review, 6(5), 409-430.

Burchell, J. \& Cook, J. (2013). "CSR, co-optation and resistance: the emergence of a new agonistic relations between business and civil society”, Journal of Business Ethics, 115 (4), 741-754 Capital”. Journal of Purchasing and Supply Management, 20(2), 74-81.

Carter, C. R. \& Easton, P. L., (2011). "Sustainable supply chain management: evolution and future directions", International Journal of Physical Distribution \& Logistics Management, 4(1), 46-62

Carter, C. R., \& Rogers, D. S. (2008). “A framework of sustainable supply chain management: Moving toward new theory". International Journal of Physical Distribution and Logistics Management, 38(5), 360-387.

Casciaro, T., \& Piskorski, M. J. (2005). "Power imbalance, mutual dependence and constraint absorption; a closer look at resource dependency theory". Administrative Science Quarterly, 5(5), 167-199

CHAK (2015). Kenyan Health Sector. Retrieved from:: www.chak.or.ke. November 2017

Chen, C. M., \& Delmas, M. (2011). "Measuring corporate social performance: An efficiency perspective". Journal of Production and Operations Management, 20(6), 789-804.

CIPS (2012). Sustainable Procurement Practices. Retrieved from: https://www.cips.org. November 2017

CIPS (2012). The Official CIPS Course Book: Environmental, Sustainability and CSR Performance. Retrieved from: www.cips.org. November 2017

CIPS (2013). Ethical Purchasing Practices. Retrieved from https://www.cips.org. November 2017 
International Journal of Supply Chain and Logistics

ISSSN 2520-3983 (Online)

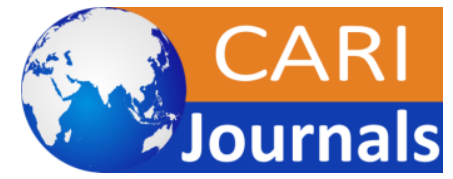

Vol. 4, Issue No.1, pp 93 - 118, 2020

www.carijournals.org

Closs, D.J., Speier, C., \& Meacham, N. (2011). "Sustainability to support end-to-end value chains: the role of supply chain management. Journal of the Academy of Marketing Science", 3(9), 101-116.

Cooper, D. R., \& Schindler, P. S. (2008). Business research methods, (10th ed.). London: McGraw-Hill International.

Craig, R.C., \& Dale, S.R., (2008). "A framework of sustainable supply chain management: moving toward new theory", International Journal of Physical Distribution \& Logistics Management, 38(5), 360-387.

Crespin-Mazet, F. \& Dontenwill, E. (2012). "Sustainable procurement: Building legitimacy in the supply network", Journal of Purchasing and Supply Management, 18 (4), 207-217.

Daniel, F.F \& Manjyot, B. (2012). "Environmental Regulation with supply chains: company private and public regulation". Centre for Environmental Policy, School of Public Affairs. Unpublished PhD Thesis: American University.

Danish Architecture Centre (2013). Cultural Sustainabilty: Montreal's Tradition. Sustainable Cities. Retrieved from http://www.dac.dk. November 2017

DJSI (2009). "Corporate Sustainability", Dow Jones Sustainability Indexes. Retrieved from www.sustainability-index.com.

Drees, J. M., \& Heugens, P. P. (2013). "Synthesizing and extending resource dependence theory: A meta-analysis". Journal of Management, 3(9), 1666-1698.

Dunn, S. D. (2010). Statistics and Data analysis for the Behavioural Science: Mc Graw Hill Ethics Quarterly, 14 (2), 243-62

Fullerton, K., (2017). "Reflecting on Rwanda's plastic ban”. International Development Journal. Retrieved from: https://idjournal.co.uk. November, 2017

George, A., Andrew, K., \& Christopher, C. (2012). “4Es and 4 Poles of Sustainability: Redifining sustainability in the build environment". Structural Survey, 30 (5), 423-422

Gimenez, C., \& Tachizawa, E. M. (2012). "Extending sustainability to suppliers: a systematic literature review", International Journal of Supply Chain Management, 17(5), 531-543.

Gold, S., Seuring, S. \& Beske, P. (2010). "Sustainable supply chain management and interorganizational resources: a literature review", Corporate Social Responsibility and Environmental Management, 17(4), 230-245

Grandia, J., Steijn, B., \& Kuipers, B., (2015). It is not easy being green: Increasing sustainable public behavior, Innovation. The European Journal of Social Science Research,

Hall, J. \& Matos, S. (2010). "Incorporating impoverished communities in sustainable supply chains", International Journal of Physical Distribution \& Logistics Management, 40 (2), 124-147. 
International Journal of Supply Chain and Logistics

ISSSN 2520-3983 (Online)

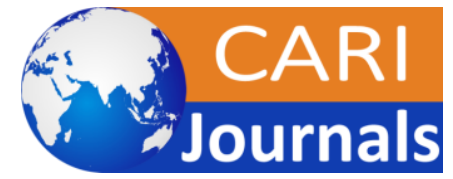

Vol. 4, Issue No.1, pp 93 - 118, 2020

www.carijournals.org

Hassini, E., Surti, C. \& Searcy, C. (2012). “A literature review and a case study of sustainable supply chains with a focus on metrics", International Journal of Production Economics, 14(1), 69-82

Health Sector (2014). Kenya Health Human Resource Strategy 2014-2018, December 2014, available at www.health.go.ke

Hsueh, C. F. (2015). A bilevel programming model for corporate social responsibility collaboration in sustainable supply chain management. Transportation Research Part E: Logistics and Transportation Review, 7(3), 84-95.

Hult, M. (2011). "Market-focused sustainability: market orientation plus". Journal of the Academy of Marketing Science, 3(9), 1-6.

Hussein, R. \& Shale, I. (2014). Effects of Sustainable Procurement Practices on Organizational Performance In Manufacturing Sector In Kenya: A Case of Unilever Kenya Limited. European Journal of Business Management, 1(1), 417-438.

Johnsen, T., Miemczyk, J. \& Howard, M. (2016). A systematic literature review of sustainable purchasing and supply research: Theoretical perspectives and opportunities for IMP-based research. Industrial Marketing Management

Jonathan, H. \& Diane, H. (2014). "Sustainable food procurement in British and Irish Zoos", British Good Journal, 116 (10), 1636-165

Kauppi, K. (2013). "Extending the use of institutional theory in operations and supply chain management research: review and research suggestions", International Journal of Operations and Production Management, 33(10), 1318-1345.

Kenya Health Sector Report (2016). Opportunities for the Dutch Life Sciences \& Health Sector. Netherlands Enterprise Agency, Nairobi.

Kenya Medical Practitioners and Dentists Board (2017). A list of licensed private hospitalsin Kenya. Retrieved from http://medicalboard.co.ke/. November, 2017

Kenyon, P., Campbell, F., \& Hawkey, E. (2010). “Gap and Nike: no sweat”, BBC News, Retrieved from ww.emeraldinsight.com/ November, 2017

Kibert, C.J. (2008). Sustainable Construction, Green Building Design and Delivery (2nd Ed), John Wiley \& Sons Inc, Hoboken, NJ

Kisaka, S. E., \& Anthony, M. (2014). An analysis of the presence of an entrepreneurial culture in Kenya: An application of the population ecology theory and the resource dependence theory. European Journal of Business and Management, 7(6), 184-191.

Kombo, D. \& Tromp, D. (2013). Proposal and Thesis Writing, an introduction. Nairobi: Pauline Publications Africa.

Kothari, C.R. (2014). Research Methodology; Methods \& Techniques (2 ${ }^{\text {nd }}$ ed.). New Delhi; New Age International Press Limited 
International Journal of Supply Chain and Logistics

ISSSN 2520-3983 (Online)

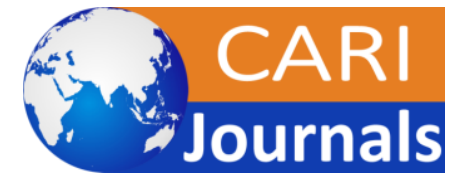

Vol. 4, Issue No.1, pp 93 - 118, 2020

www.carijournals.org

Kour, S. (2014). Ethical and Legal issues in Educational research. Indian Journal of Applied Research, 4(6) 23-45

Kumar, S., \& Putnam, V. (2008). "Cradle to Cradle: Reverse Logistics Strategies and Opportunities Across Three Industry Sectors." International Journal of Production Economics 115 (2), 305-315.

Kumar, S., Luthra, S., \& Haleem, A. (2013). Customer involvement in greening the supply chain: An interpretive structural modeling methodology. Journal of Industrial Engineering International, 9(1), 1-13.

London, T. \& Hart, S. (2010). Next Generation Business Strategies for the Base of the Pyramid: New Approaches for Building Mutual Value, Financial Times/Prentice Hall, New Jersey, NJ. Management Orientation", Journal of Business Ethics, 92(2), 305-322.

Mandar, D., Lars, B. \& Nicollete, L. (2016). Sustainable Supply Management as a purchasing capability. A power and dependency perspective. International Journal of Operations and Production Management, 36(1), 2-22.

Marc, B., \& Marion, J., (2011). "Making Globalization Socially Sustainable”. World Trade Organization and International Labour Organization. Switzerland.

Maria, A.O, Goran, S. \& Carmen, P. (2014). "Implementation, Monitoring and Evaluation of Sustainable Business Practices", Corporate Governance, 14(14), 515-530.

Meehan, J. \& Bryde, D.J. (2014). "Procuring sustainably in social housing: The role of social

Meysam, M. A., (2013). "Supply Chain Integration Model: Practices and Customer Values, unpublished PhD Thesis. Universidade Nova de Lisboa, Portugal.

Minglang, T., Ming, L. \& Wai, P.W. (2014). Supply chain management: A closed-loop network hierarchical approach. Industrial management and data systems, 115(3), 436-461

Ministry of Foreign Affairs (2016). Kenyan Heath Sector: Market Study Report. Nairobi,

Minkyun, K. \& Sangmi, C. (2017). Implementing Environmental Practices for Accomplishing sustainable green supply chain management. Sustainability

Mohammad, S. (2015). Integrated Supply Chain Model for Sustainable Manufacturing: A system dynamics approach. Published online: 6(7), 155-399 